\title{
Dromedary Milk Protein Hydrolysates Show Enhanced Antioxidant and Functional Properties
}

\author{
Olfa Oussaief**๑๑, Zeineb \\ Jrad $^{1}{ }^{\circ}$, Isabelle $\mathrm{Adt}^{2}{ }^{(0)}$, \\ Touhami Khorchani ${ }^{10}$ \\ and Halima El-Hatmi ${ }^{1,3}$ \\ 'Livestock and Wildlife Laboratory, \\ Arid Lands Institute, University of \\ Gabes, 4119 Medenine, Tunisia \\ 2University of Lyon, University \\ Claude Bernard Lyon 1, ISARA Lyon, \\ BioDyMIA - Equipe Mixte d'Accueil \\ n³733, rue Henri de Boissieu, 01000 \\ Bourg en Bresse, France \\ ${ }^{3}$ Department of Food, High Institute \\ of Applied Biology, University of \\ Gabes, 4119 Medenine, Tunisia
}

Received: 20 April 2019 Accepted: 21 May 2020
*Corresponding author:

Phone: +21693005049

Fax: +21675633006

E-mail: olfa.loussaief@hotmail.fr

\section{SUMMARY}

Research background. Milk protein hydrolysates have received particular attention due to their health-promoting effects. Dromedary milk differs from the milk of other dairy animals in the composition and structure of its protein components, which give it unique properties. The bioactivity and functionality of whole dromedary milk proteins and their enzymatic hydrolysates have not received much attention, hence this study aims to investigate the effect of enzymatic hydrolysis of dromedary milk proteins on their antioxidant activities and functional properties.

Experimental approach. Dromedary milk proteins were treated using four proteolytic enzymes (pepsin, trypsin, a-chymotrypsin and papain) and two mixtures of enzymes (pancreatin and pronase). The degree of hydrolysis was measured to verify the hydrolysis of the proteins. The sodium dodecyl sulfate polyacrylamide gel electrophoresis (SDS-PAGE) and gel filtration chromatography served to determine the molecular mass distribution of the hydrolysates while reversed phase-high performance liquid chromatography (RP-HPLC) was conducted to explore their hydrophobicity. The antioxidant activities were evaluated using various in vitro tests, including 2,2-diphenyl-1-picrylhydrazyl (DPPH) and 2,2'-azino-bis(3-ethylbenzothiazoline-6-sulfonic acid (ABTS) radical scavenging capacities, iron(III) reducing ability and chelating activity. Besides, functional properties such as solubility, foaming and emulsification were assessed.

Results and conclusions. Dromedary milk protein hydrolysates exhibited different degrees of hydrolysis ranging from 17.69 to $41.86 \%$. Apart from that, the hydrolysates showed different electrophoretic patterns, molecular mass distribution and RP-HPLC profiles demonstrating the heterogeneity of the resulting peptides in terms of molecular mass and polarity. The hydrolysates displayed significantly higher antioxidant capacities than the undigested proteins at all the tested concentrations. Iron(II) chelating activity was the most improved assay after proteolysis and the hydrolysate generated with pancreatin had the highest chelating power. Dromedary milk protein hydrolysates possessed good solubility (>89\%). Further, foaming and emulsifying properties of dromedary milk proteins were enhanced after their proteolysis. These interfacial properties were influenced by the enzymes employed during proteolysis.

Novelty and scientific contribution. Enzymatic hydrolysis of dromedary milk proteins is an effective tool to obtain protein hydrolysates with great antioxidant and functional properties. These results suggest that dromedary milk protein hydrolysates could be used as a natural source of antioxidant peptides to formulate functional foods and nutraceuticals.

Key words: dromedary milk, proteolytic enzymes, protein hydrolysate, antioxidant activity, functional properties

\section{INTRODUCTION}

Endogenous generation of reactive oxygen species (ROS) is unavoidable in aerobic organisms because it is a consequence of normal metabolic processes. At normal levels, ROS are involved in mediating several cellular responses comprising cell growth and immunity 
(1). The production of ROS is activated by exogenous sources such as exposure to air pollutants, radiation, pesticides and ozone. Thus, the excess of ROS leads to oxidative stress, which is related to the occurrence of numerous ailments like cancer, cardiovascular, inflammatory diseases and neurodegenerative disorders (2). Organisms possess antioxidant defence systems against oxidative stress like antioxidant thiols and enzymes. Nevertheless, under pathological or extreme environmental conditions, endogenous antioxidants are not sufficient to remove ROS and external sources of antioxidants are required (3). Moreover, ROS induce lipid peroxidation in foods which causes the reduction of their nutritive value and their shelf life (4). Hence, various synthetic antioxidants have been extensively utilized in pharmaceutical and food industries to prevent oxidative damage. However, the use of synthetic antioxidants is restricted due to their potential toxicity (5). Accordingly, there is an increasing interest in finding new and safe antioxidants from natural sources.

A large number of milk-derived peptides have been found to be a good source of natural antioxidants (6). Bioactive peptides could be released from milk proteins via enzymatic hydrolysis, which is the most efficient way to generate peptides with multiple biological activities like antioxidant, antimicrobial, anticancer and anti-inflammatory activities (6). Enzymatic proteolysis also improves protein functionality in terms of solubility, emulsification, and foaming ability. Therefore, protein hydrolysates have wide application in the food industry. They can be used as additives in beverages since they have excellent solubility. Besides, they could be used as foaming agents in ice cream, mousse and whipped toppings or as emulsifiers in salad dressings, meat products, cakes and so on $(7,8)$.

Dromedary (Camelus dromedarius) milk differs from the milk of other dairy animals in the composition and structure of its proteins, which gives it different functional and bioactive properties. In fact, immunoglobulins, camel whey basic protein, peptidoglycan recognition protein and whey acidic protein are specific proteins found only in dromedary milk. Furthermore, dromedary milk is similar to human milk since it contains low amounts of $\mathrm{K}$-casein and high amounts of $\beta$-casein, lactoferrin and $a$-lactalbumin. It also lacks $\beta$-lactoglobulin, which makes it useful for those with cow's milk allergy (9). Many studies have reported the medicinal properties of dromedary milk like anticancer, anti-diabetic and antihypertensive capacities as well as the ability to reduce autism symptoms $(10,11)$. These therapeutic properties were attributed to its richness in vitamin $\mathrm{C}$ and minerals, its unique protein composition as well as its potential bioactive peptides released during the gastrointestinal digestion of milk proteins (11).

Functional and various bioactive properties of peptides obtained from cow's milk proteins after enzymatic hydrolysis have been widely studied $(12,13)$. Recently, bioactive peptides from dromedary milk have received great interest. The effect of enzymatic hydrolysis on the antioxidant activities of whey, casein or some individual proteins from dromedary milk has been reported $(14,15)$. However, whole dromedary milk proteins and their hydrolysates have not received attention with respect to their bioactivity and functional properties. Therefore, this study investigates the antioxidant and functional properties of whole dromedary milk proteins before and after enzymatic hydrolysis by four proteolytic enzymes (pepsin, trypsin, a-chymotrypsin and papain) and two mixtures of enzymes (pancreatin and pronase).

\section{MATERIALS AND METHODS}

\section{Materials}

Dromedary milk was obtained from a dromedary (Camelus dromedarius) herd belonging to the Livestock and Wildlife laboratory, Arid Lands Institute of Medenine, Tunisia. Fresh dromedary milk was defatted by centrifugation (5000 $\times g, 30 \mathrm{~min}, 4^{\circ} \mathrm{C}$, centrifuge Sorvall Lynx 6000; Thermo Fisher Scientific, Waltham, MA, USA). Then, it was lyophilized in a freeze dryer (Christ Gamma 1-20; Martin Christ GmbH, Osterode am Harz, Germany) and kept at $-20^{\circ} \mathrm{C}$.

Pepsin from porcine stomach mucosa and pancreatin from porcine pancreas were obtained from Bio Basic (Ontario, Canada). Trypsin from porcine pancreas, a-chymotrypsin from bovine pancreas, papain from Carica papaya and pronase from Streptomyces griseus were purchased from Sigma-Aldrich, Merck (St. Louis, MO, USA). All other chemicals and reagents used were of analytical grade.

\section{Enzymatic hydrolysis of dromedary milk proteins}

Dromedary milk protein hydrolysis was performed as described by Oussaief et al. (16) with slight modifications. Dromedary skimmed milk was resuspended on protein basis at 2.5 $\%(m / V)$ in ultrapure water and the $\mathrm{pH}$ of this solution was adjusted to the optimal $\mathrm{pH}$ value of enzymes: 2 for pepsin, 8 for trypsin, a-chymotrypsin, pancreatin and pronase and 6.5 for papain, as given by the manufacturer. The hydrolysis was started by adding the enzymes to proteins at a ratio of 1:100 (by mass). The temperature of the reactions was maintained at $37^{\circ} \mathrm{C}$ using a shaking water bath (LSB-030S; Daihan Labtech Co., Namyangju-si, Republic of Korea) at 150 rpm. After hydrolysis for $6 \mathrm{~h}$, the enzymes were inactivated by heating the samples for $20 \mathrm{~min}$ at $85^{\circ} \mathrm{C}$. Dromedary milk protein hydrolysates (DMPHs) were neutralized to $\mathrm{pH}=7$ and centrifuged at $10000 \times g$ for $15 \mathrm{~min}$ at $4{ }^{\circ} \mathrm{C}$. Then, the supernatants were freeze-dried and kept at $-20{ }^{\circ} \mathrm{C}$ for further use. Control samples containing undigested dromedary milk proteins (UDMP) undergo the same procedure as the hydrolysates but without the addition of enzymes.

\section{Degree of hydrolysis}

Degree of hydrolysis (DH) was measured as described by Hoyle and Merritt (17). A volume of $1 \mathrm{~mL}$ of each dromedary milk protein hydrolysate was added to $1 \mathrm{~mL}$ of a solution of 
$20 \%(\mathrm{~m} / \mathrm{V})$ trichloroacetic acid (TCA) and the mixtures were incubated at $25^{\circ} \mathrm{C}$ for $30 \mathrm{~min}$. Then, the mixtures were centrifuged at $10000 \times \mathrm{g}$ for $10 \mathrm{~min}$ at $4{ }^{\circ} \mathrm{C}$ to obtain $10 \%(\mathrm{~m} / \mathrm{V})$ TCA-soluble fraction. The total protein content of both $10 \%$ $(\mathrm{m} / \mathrm{V})$ TCA-soluble fractions and samples of dromedary milk protein hydrolysates were determined by the method of Lowry et al. (18). The $\mathrm{DH}$ value was calculated as the ratio of the 10 $\%(m / V)$ TCA-soluble protein to the total protein in the sample, expressed as a percentage.

\section{Gel electrophoresis}

Sodium dodecyl sulfate polyacrylamide gel electrophoresis (SDS-PAGE) was carried out according to the method of Laemmli and Favre (19) using a $5 \%(\mathrm{~m} / \mathrm{V})$ stacking gel and a $15 \%(\mathrm{~m} / \mathrm{V})$ separating gel. Samples were dissolved in a sample buffer (62.5 mM Tris-HCl buffer (pH=6.8), $2 \%(\mathrm{~m} / \mathrm{V}) \mathrm{SDS}$, $10 \%(V / V)$ glycerol, $5 \%$ (V/V) $\beta$-mercaptoethanol and 0.0025 $\%(m / V)$ bromophenol blue) at 1:1 (V/V) ratio and boiled for 3 min at $100^{\circ} \mathrm{C}$. Volumes of $10 \mu \mathrm{L}$ of samples at $2 \mathrm{mg} / \mathrm{mL}$ proteins were loaded in the gel. After electrophoresis, proteins were fixed with $12 \%(\mathrm{~m} / \mathrm{V})$ TCA for $20 \mathrm{~min}$, stained with $0.1 \%(\mathrm{~m} / \mathrm{V})$ Coomassie Brilliant Blue R-250 solubilized in a mixture of $50 \%$ (V/V) ethanol and $2 \%(V / V)$ TCA for $1 \mathrm{~h}$ and destained by several washes in $30 \%(V / V)$ ethanol, $10 \%(V / V)$ acetic acid solution.

\section{Gel filtration chromatography}

Molecular mass distribution was determined using gel filtration chromatography by a Nexera XR HPLC system (Shimadzu, Tokyo, Japan) on a Superdex ${ }^{\circledast}$ Peptide PE 7.5/300 column (GE Healthcare, Uppsala, Sweden) as described by Dupas et al. (20). A volume of $50 \mu \mathrm{L}$ from each sample, filtered through a $0.45-\mu \mathrm{m}$ syringe filters, was injected into the column. Elution was achieved at a flow rate of $0.25 \mathrm{~mL} / \mathrm{min}$ with $30 \%(V / V)$ of $0.1 \%(V / V)$ trifluoroacetic acid (TFA) in acetonitrile and $70 \%(V / V)$ of $0.1 \%(V / V)$ TFA in water during 120 min. The elution was controlled spectrophotometrically at 215 nm (Cecil CE 2041; Cecil Instruments Ltd, Cambridge, UK). The column was previously calibrated using standard proteins: cytochrome C (12 $400 \mathrm{Da})$, aprotonin (6500 Da), substance P (1348 Da), glycine 6 (360 Da), glycine 3 (189 Da) and glycine (75 Da).

\section{Reversed-phase high performance liquid chromatography}

Reversed-phase high performance liquid chromatography (RP-HPLC) analysis was conducted using a Nexera XR HPLC system (Shimadzu) equipped with a C18 Omnispher column ( $250 \mathrm{~mm} \times 4.6 \mathrm{~mm}, 5 \mu \mathrm{m}$; GE Healthcare) as reported by Adt et al. (21). Samples were filtered through a 0.45 $\mu \mathrm{m}$ syringe filter (Millipore Corp., Billerica, MA, USA) and a volume of $50 \mu \mathrm{L}$ of each filtered sample was loaded onto the column. Peptides were eluted with $0.1 \%(V / V)$ TFA in water for $10 \mathrm{~min}$, followed by an 80-minute linear gradient from 0 to $50 \%(V / V)$ of acetonitrile in the presence of $0.1 \%$ TFA, then a linear gradient of 50 to $75 \%(V / V)$ acetonitrile in $0.1 \%$ (V/V) TFA during $10 \mathrm{~min}$. The flow rate was $1 \mathrm{~mL} / \mathrm{min}$ and the separation was monitored spectrophotometrically at $215 \mathrm{~nm}$.

\section{Antioxidant properties}

\section{DPPH radical-scavenging activity}

The scavenging activity of 2,2-diphenyl-1-piycrylhydrazyl (DPPH) radical was measured by the method of Bersuder et al. (22) with some modifications. A volume of $1 \mathrm{~mL}$ of each sample $(1-7 \mathrm{mg} / \mathrm{mL}$ ) was mixed with $1 \mathrm{~mL}$ of $125 \mu \mathrm{M} \mathrm{DPPH}$ in ethanol, kept in the dark for $60 \mathrm{~min}$ at room temperature and then the absorbance was measured at $517 \mathrm{~nm}$ using an UV-Vis spectrophotometer (Cecil CE 2041; Cecil Instruments Ltd). The control was prepared in the same way, except that distilled water was used instead of the sample. The DPPH radical-scavenging activity was calculated from the following equation:

$$
\text { DPPH radical scavenging activity }=\frac{A_{c}-A_{s}}{A_{c}} \cdot 100
$$

where $A_{c}$ is the absorbance of the control and $A_{s}$ is the absorbance of the sample.

\section{ABTS radical-scavenging activity}

The method of Re et al. (23) was used to determine the scavenging activity of the 2,2'-azino-bis(3-ethylbenzothiazoline-6-sulfonic acid (ABTS) radical, with minor modifications. The ABTS radical was generated by dissolving $7 \mathrm{mM}$ of ABTS cation in $2.45 \mathrm{mM}$ potassium peroxydisulfate and the mixture was kept in the dark at room temperature for $14 \mathrm{~h}$. The ABTS radical cation solution was then diluted with sodium phosphate buffer ( $5 \mathrm{mM}, \mathrm{pH}=7.4$ ) to obtain an absorbance of 0.7 at $734 \mathrm{~nm}$. A volume of $0.25 \mathrm{~mL}$ of each sample with a concentration range from 0.25 to $1 \mathrm{mg} / \mathrm{mL}$ was added to 1 $\mathrm{mL}$ of the diluted ABTS radical reagent and left for $10 \mathrm{~min}$ at room temperature in dark conditions. Then, the absorbance was read at $734 \mathrm{~nm}$. For the control, the distilled water was used instead of the sample. The ABTS scavenging effect was calculated using Eq. 1.

\section{Ferric reducing antioxidant power}

The reducing power of iron(III) ions was performed according to Wu et al. (24) with some modifications. A volume of $1 \mathrm{~mL}$ aliquot of each sample at different concentrations (1-20 $\mathrm{mg} / \mathrm{mL}$ ) was added to $1 \mathrm{~mL}$ phosphate buffer $(0.2 \mathrm{M}, \mathrm{pH}=6.6)$ and $1 \mathrm{~mL}$ of $1 \%(\mathrm{~m} / \mathrm{V})$ of potassium hexacyanoferrate(III) and then heated for $20 \mathrm{~min}$ at $50^{\circ} \mathrm{C}$ in a water bath. Then, $1 \mathrm{~mL}$ of $10 \%(m / V)$ TCA was added and the reaction mixtures were centrifuged for $10 \mathrm{~min}$ at $3000 \times \mathrm{g}$. Finally, a volume of $1 \mathrm{~mL}$ of the supernatant solution of each sample was added to $1 \mathrm{~mL}$ of distilled water and $0.2 \mathrm{~mL}$ of $0.1 \%(\mathrm{~m} / \mathrm{V})$ iron(III) chloride. After a 10-minute reaction, the absorbance of the resulting solution was measured at $700 \mathrm{~nm}$. The control was prepared using distilled water instead of the sample. 
Iron(II) chelating activity

The chelating ability of iron(II) ions was estimated as reported by Zhu et al. (25) with minor modifications. A volume of $1 \mathrm{~mL}$ aliquot from each sample solution $(0.5-3 \mathrm{mg} / \mathrm{mL})$ and $1 \mathrm{~mL}$ distilled water were added to $0.05 \mathrm{~mL} \mathrm{FeCl}_{2}(2 \mathrm{mM})$. The mixtures were left for $30 \mathrm{~s}$ at room temperature. Then, a volume of $0.1 \mathrm{~mL}$ ferrozine solution $(5 \mathrm{mM})$ was added to the reaction and the mixtures were incubated for $10 \mathrm{~min}$ at room temperature. The control was prepared in the same way, substituting the sample with distilled water. The absorbance was measured at $562 \mathrm{~nm}$ and the iron(II) chelating activity was calculated using the following formula:

Chelating activity $=1-\frac{A_{562 \mathrm{~nm}}(\text { control })-A_{562 \mathrm{~nm}} \text { (sample) }}{A_{562 \mathrm{~nm}} \text { (control) }} \cdot 100$

\section{Functional properties}

Solubility

Solubility was estimated by the method of Tsumura et al. (26). Samples (100 mg) were dispersed in $10 \mathrm{~mL}$ of distilled water and the $\mathrm{pH}$ of the mixture was regulated to values from 3.0 to 9.0 with $2 \mathrm{M} \mathrm{HCl}$ or $2 \mathrm{M} \mathrm{NaOH}$ solutions. The mixtures were stirred at room temperature for $10 \mathrm{~min}$ and centrifuged at $8000 \times g$ for $10 \mathrm{~min}$. The total protein content of the supernatants and samples of dromedary milk protein hydrolysates were determined by the method of Lowry et al. (18). Protein solubility was calculated as follows:

$$
\text { Protein solubility }=\frac{w(\text { protein })_{\text {supernatant }}}{w(\text { protein })_{\text {sample }}} \cdot 100
$$

Foaming properties

Foaming properties were tested by the method of Shahidi et al. (27). A volume of $30 \mathrm{~mL}$ of $1 \%(\mathrm{~m} / \mathrm{V})$ sample was homogenized at room temperature using a blender (DOM216; DomoClip $^{\oplus}$, Mundelsheim, Germany) at the highest speed for $1 \mathrm{~min}$, poured into a graduated cylinder and the total volume was recorded immediately. Foaming capacity was calculated according the following formula:

$$
\text { Foaming capacity }=\frac{V_{B}-V_{A}}{V_{A}} \cdot 100
$$

where $V_{B}$ is the volume after whipping $(\mathrm{mL})$ at 0 min and $V_{A}$ is the volume before whipping $(\mathrm{mL})$. After $30 \mathrm{~min}$ of standing at room temperature, the volume of whipped samples was recorded. Foam stability was calculated as follows:

$$
\text { Foam stability }=\frac{V_{c}-V_{A}}{V_{A}} \cdot 100
$$

where $V_{A}$ is the volume before whipping $(\mathrm{mL})$, and $V_{C}$ is the volume after 30 min of rest at room temperature $(\mathrm{mL})$.

\section{Emulsifying properties}

The emulsifying activity index (EAI) and the emulsion stability index (ESI) were determined by the method of Pearce and Kinsella (28) with minor modifications. A volume of $30 \mathrm{~mL}$ of $1 \%(\mathrm{~m} / \mathrm{V})$ samples was homogenized at room temperature with $10 \mathrm{~mL}$ of corn oil for $1 \mathrm{~min}$ using a blender (DOM216; DomoClip ${ }^{\oplus}$ ) at the highest speed. A $50-\mu \mathrm{L}$ aliquot of the emulsion was taken from the bottom of the container at 0 and 10 min after homogenization and diluted 100 times with $0.1 \%$ $(m / V)$ SDS solution. The absorbance of the diluted solutions was measured at $500 \mathrm{~nm}$ immediately $\left(A_{0}\right)$ and $10 \mathrm{~min}\left(A_{10}\right)$ after the formation of the emulsion. The EAI and ESI were calculated as follows:

and

$$
\mathrm{EAI}=\frac{2 \cdot\left(2.303 \cdot A_{0} / I\right) \cdot \mathrm{DF}}{\varphi \cdot c \cdot 10000}
$$

$$
\mathrm{ESI}=\frac{A_{0} \cdot \Delta t}{A_{0}-A_{10}}
$$

where $I$ is cuvette length ( $1 \mathrm{~cm}$ ), DF is dilution factor (100), $A_{0}$ and $A_{10}$ are the absorbance at time $t=0$ and $10 \mathrm{~min}$, respectively, $c$ is sample concentration $(\mathrm{g} / \mathrm{mL})$, and $\varphi$ is the oil fraction (0.25).

\section{Statistical analysis}

All experiments were conducted in triplicate. The results were statistically assessed using SPSS v. 22.0 (29). The one-way analysis of variance (ANOVA) was performed with Tukey's test to determine the significance at $5 \%$ probability level.

\section{RESULTS AND DISCUSSION}

\section{Preparation of dromedary milk protein hydrolysates}

In this study, various proteases were employed to hydrolyse dromedary milk proteins in order to assess the functionality of the generated protein hydrolysates. The extent of proteolysis in the hydrolysates was assessed by determining the degree of hydrolysis (DH). Fig. 1 shows the kinetic curves of dromedary milk proteins. During the first $2 \mathrm{~h}$ of hydrolysis, the $\mathrm{DH}$ increased rapidly, indicating that dromedary milk proteins contain many cleavage sites for the used enzymes. After that, the hydrolysis rate decreased, which might be a result of the reduction in available cleavage sites for the enzymes. The typical shape of hydrolysis curves was found previously for cow's milk protein hydrolysates (30) and goat's milk protein hydrolysates (31).

Pronase-treated hydrolysates showed the highest $\mathrm{DH}$ values, whereas pepsin-treated hydrolysates showed the lowest ones, at each time interval of hydrolysis. After $6 \mathrm{~h}$ of hydrolysis, $\mathrm{DH}$ values were 17.69, 25.41, 31.35, 39.48, 18.79 and 41.86 $\%$ for DMPH treated with pepsin (Pep), trypsin (Try), a-chymotrypsin (Chy), pancreatin (Pan), papain (Pap) and pronase (Pro), respectively. Different $\mathrm{DH}$ values of milk proteins have been reported in the literature due to the variability of the 


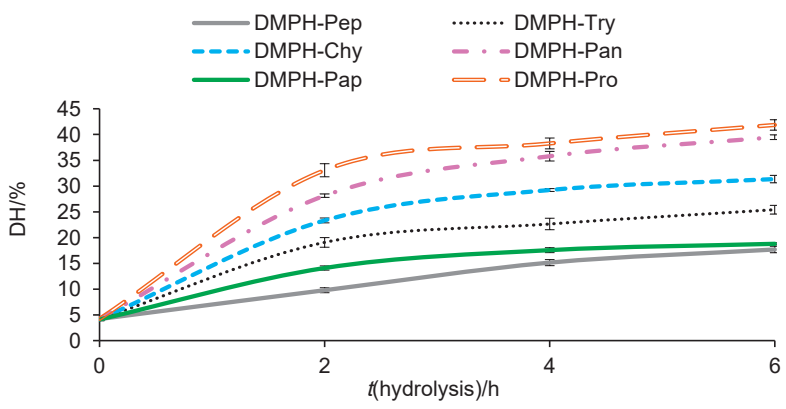

Fig. 1. Degree of hydrolysis (DH) of dromedary milk proteins (DMPH) treated with pepsin (DMPH-Pep), trypsin (DMPH-Try), a-chymotrypsin (DMPH-Chy), pancreatin (DMPH-Pan), papain (DMPH-Pap) and pronase (DMPH-Pro)

specificity of the enzymes used and the amino acid sequence of proteins. Banach et al. (32) reported that the hydrolysis of cow's milk proteins with pepsin for $12 \mathrm{~h}$ lead to a $\mathrm{DH}$ of 5.7 $\%$, whereas the hydrolysis of these proteins with papain for $3 \mathrm{~h}$ and trypsin for $1 \mathrm{~h}$ showed a DH values of 9.8 and $14.1 \%$, respectively. The $\mathrm{DH}$ values of cow's milk casein hydrolysates after $24 \mathrm{~h}$ of hydrolysis with trypsin, pancreatin and papain were $20.68,20.91$ and $22.06 \%$, respectively (33). For dromedary casein hydrolysates, the $\mathrm{DH}$ was found to be 22 and $16 \%$ after $6 \mathrm{~h}$ of hydrolysis with a-chymotrypsin and papain, respectively (15).The $\mathrm{DH}$ values in the current study show that the used enzymes have a broad specificity on dromedary milk proteins compared with the above $\mathrm{DH}$ values.

The significant difference $(p<0.05)$ in the $\mathrm{DH}$ among the hydrolysates of this study could be mainly due to the specificity of the used enzymes. Pronase has very broad specificity of action towards proteins since it contains several proteinases and peptidases from Streptomyces griseus (34). Pancreatin is a mixture of enzymes liberated by the pancreas and it also has a broad specificity, but it has a preference for Arg, Leu, Lys and Tyr (35). Papain cleaves the bonds of Lys, Arg and Phe. Chymotrypsin attacks at the carboxylic side of aromatic (Phe, Tyr and Trp) and long chain hydrophobic (Met and Leu) residues while trypsin splits peptide bonds in the carboxylic group of Arg and Lys residues. Besides, pepsin cleaves preferentially peptide bonds involving aromatic amino acids (36).

\section{Electrophoretic patterns of dromedary milk protein hydrolysates}

The SDS-PAGE profiles of UDMP and DMPH are shown in Fig. 2. In this study, dromedary milk proteins before hydrolysis were predominantly lactoferrin, camel serum albumin, caseins, camel whey basic protein and a-lactalbumin. The protein profile of the hydrolysates changed. Indeed, lactoferrin band was absent from all the hydrolysates except from those obtained with trypsin and a-chymotrypsin, in which some traces of this protein were still noticed. In addition, bands of camel serum albumin and caseins were totally hydrolysed by all the enzymes into fragments invisible in the gel. Kumar et al. (15) also reported that dromedary milk caseins were rapidly hydrolysed with a-chymotrypsin and papain owing to their open structure. Camel whey base protein band was observed only in pepsin-treated hydrolysates. Except pronase, all the used enzymes exhibited limited degradation ability of a-lactalbumin. Banach et al. (32) reported that the hydrolysis of cow's milk proteins with pepsin, trypsin and a-chymotrypsin degraded partially $a$-lactalbumin and $\beta$-lactoglobulin, whereas the rest of the proteins were all degraded into fragments invisible in the gel. The resistance of a-lactalbumin to proteolysis was attributed to its compact globular structure which hides its cleavage sites (14). Overall, most of high-molecular-mass proteins were degraded after enzymatic hydrolysis. The differences in enzyme specificity towards proteins might cause variability in protein degradation. These results suggest that the highest proteolysis occurred with pronase and the lowest with pepsin, which is in agreement with the results obtained for $\mathrm{DH}$.

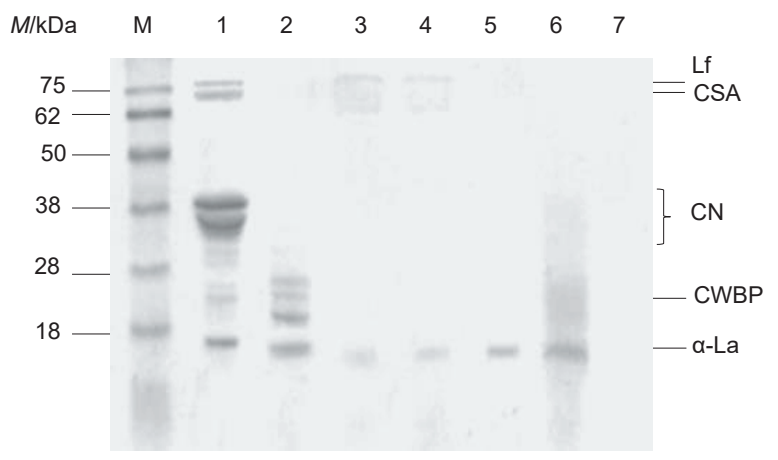

Fig. 2. SDS-PAGE of undigested dromedary milk proteins (UDMP) and dromedary milk protein hydrolysates (DMPH) after $6 \mathrm{~h}$ of hydrolysis. Lane $\mathrm{M}=$ molecular mass marker, lane $1=\mathrm{UDMP}$, lane $2=\mathrm{DMPH}-$ -Pep, lane 3=DMPH-Try, lane 4=DMPH-Chy, lane 5=DMPH-Pan, lane 6=DMPH-Pap, lane 7=DMPH-Pro; Lf=lactoferrin, CSA=camelin serum albumin, $\mathrm{CN}=$ caseins, $\mathrm{CWBP}=$ camel whey basic protein and $\mathrm{a}$-La $=\mathrm{a}$-lactalbumin

\section{Molecular mass distribution of dromedary milk protein hydrolysates}

Gel filtration chromatography was performed to determine the molecular mass distribution of peptides in each sample (Table 1). UDMP had the lowest amount of low molecular mass peptides below 1 kDa (23.15 \%). After hydrolysis, the level of peptides with molecular mass higher than 10 kDa decreased, while the level of low molecular mass peptides $(<1 \mathrm{kDa})$ increased, which confirms the generation of shorter peptides during the enzymatic hydrolysis. The differences in molecular mass peptide distribution depended on the used enzyme. Besides, the content of low molecular mass peptides positively correlated with the $\mathrm{DH}$ of the hydrolysates. In fact, hydrolysate DMPH-Pro, with the highest DH, comprised the highest amount of peptides with molecular mass under $1 \mathrm{kDa}$ (86.41\%), followed by DMPH-Pan (82.02\%). For the other hydrolysates, the amount of low molecular mass peptides below $1 \mathrm{kDa}$ ranged from 46.22 to $68.38 \%$. Amiot et al. (37) reported that the hydrolysis of cow's milk protein 
using trypsin $(\mathrm{DH}=6 \%)$ resulted in hydrolysates containing $60 \%$ peptides with molecular mass under $3 \mathrm{kDa}$. In addition, these authors found that cow's milk protein hydrolysates obtained with a-chymotrypsin ( $\mathrm{DH}=6 \%$ ) contained $80 \%$ peptides with molecular mass below $1.2 \mathrm{kDa}$.

Table 1. Molecular mass distribution (\%) of undigested dromedary milk proteins (UDMP) and dromedary milk protein hydrolysates (DMPHs)

\begin{tabular}{ccccc}
\multirow{2}{*}{ Sample } & \multicolumn{4}{c}{$M / k D a$} \\
\cline { 2 - 5 } & $>10$ & $10-5$ & $5-1$ & $<1$ \\
UDMP & $68.31^{\mathrm{a}}$ & $0.00^{\mathrm{f}}$ & $8.54^{\mathrm{e}}$ & $23.15^{\mathrm{g}}$ \\
DMPH-Pep & $25.67^{\mathrm{b}}$ & $1.87^{\mathrm{c}}$ & $26.23^{\mathrm{b}}$ & $46.22^{\mathrm{f}}$ \\
DMPH-Try & $16.19^{\mathrm{e}}$ & $6.48^{\mathrm{a}}$ & $22.13^{\mathrm{c}}$ & $55.20^{\mathrm{d}}$ \\
DMPH-Chy & $18.06^{\mathrm{c}}$ & $2.22^{\mathrm{b}}$ & $11.35^{\mathrm{d}}$ & $68.38^{\mathrm{c}}$ \\
DMPH-Pan & $14.05^{\mathrm{f}}$ & $1.01^{\mathrm{e}}$ & $2.86^{\mathrm{g}}$ & $82.08^{\mathrm{b}}$ \\
DMPH-Pap & $16.62^{\mathrm{d}}$ & $1.07^{\mathrm{d}}$ & $30.00^{\mathrm{a}}$ & $52.31^{\mathrm{e}}$ \\
DMPH-Pro & $8.60^{\mathrm{g}}$ & $0.00^{\mathrm{f}}$ & $4.99^{\mathrm{f}}$ & $86.41^{\mathrm{a}}$
\end{tabular}

DMPHs were obtained by hydrolysis of dromedary milk proteins by pepsin (DMPH-Pep), trypsin (DMPH-Try), a-chymotrypsin (DMPH-Chy), pancreatin (DMPH-Pan), papain (DMPH-Pap) and pronase (DMPH-Pro)

a-g Different letters in the same column indicate significant differences $(p<0.05)$

\section{Analysis of dromedary milk protein hydrolysates by RP-HPLC}

RP-HPLC is a good method to investigate the hydrophobicity of proteins and peptides (21). The RP-HPLC elution profiles of UDMP and DMPH are visible in Fig. 3. A few peaks with low intensities were detected in the chromatogram of the UDMP, which indicated that they contained only a few peptides. After hydrolysis, numerous peaks were eluted between 20 and 80 min in the DMPHs, confirming the hydrolysis of dromedary milk proteins into several peptides. These results are in agreement with the DH measurements, SDS-PAGE patterns and molecular mass distribution. During proteolysis, the breakdown of every peptide bond releases two highly hydrophilic chemical groups. Subsequently, the hydrophobicity as well as the molecular mass distribution of the hydrolysates decreased compared to the native proteins (38). The hydrolysates comprised peptides with different hydrophobic and/or hydrophilic properties. In fact, both pepsin- and papain-treated hydrolysates showed the highest content of hydrophobic (high retention time) peptides. However, pronase-treated hydrolysates, with the highest $\mathrm{DH}$, contained more hydrophilic (low retention time) peptides than the other hydrolysates.
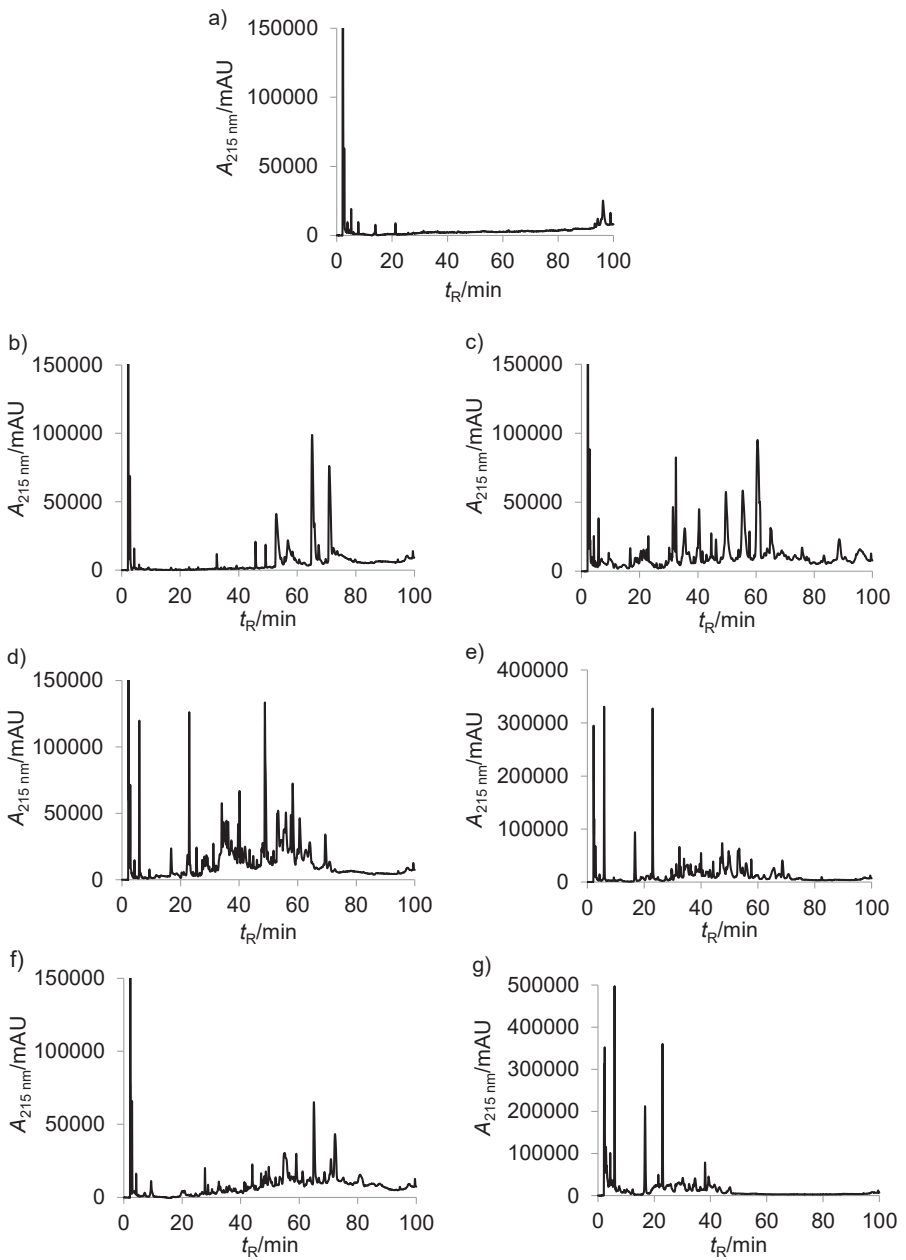

Fig. 3. Reversed phase-HPLC profiles of undigested dromedary milk proteins (UDMP) and their hydrolysates (DMPHs): a) UDMP, with b) pepsin, c) trypsin, d) a-chymotrypsin, e) pancreatin, f) papain and g) pronase 


\section{Effects of enzymatic hydrolysis on the antioxidant} activities of dromedary milk proteins

Fig. 4a reports the DPPH radical-scavenging capacity of UDMP and DMPHs, at various concentrations. Both UDMP and DMPH were able to scavenge DPPH radical in a concentration-dependent manner. DMPH possessed greater DPPH scavenging capacity than UDMP $(p<0.05)$. These results demonstrate that enzymatic hydrolysis of dromedary milk proteins leads to the liberation of peptides able to scavenge the DPPH radical (39). Whatever the concentration tested, DMPH-Pap exhibited the greatest DPPH scavenging activity $(p<0.05)$. IC $C_{50}$ defined as the concentration of samples required to inhibit $50 \%$ of the initial DPPH radical activity, was the lowest in
DMPH-Pap (3.47 mg/mL). IC 50 values were between 4.43 and $5.23 \mathrm{mg} / \mathrm{mL}$ for the rest of the hydrolysates. DMPH had higher DPPH scavenging activity than dromedary casein hydrolysates determined by Kumar et al. (15), who found that the DPPH scavenging activity did not exceed $40 \%$. These findings confirm that DPPH scavenging activity of DMPH resulted not only from the proteolysis of casein but also from the proteolysis of whey proteins. Therefore, proteolysis of whole dromedary proteins provides greater DPPH scavenging activity than casein and whey hydrolysed independently.

Fig. $4 \mathrm{~b}$ shows the results of ABTS scavenging activity of UDMP and DMPH. All the samples had the ability to quench the ABTS also in a concentration-dependent manner. ABTS
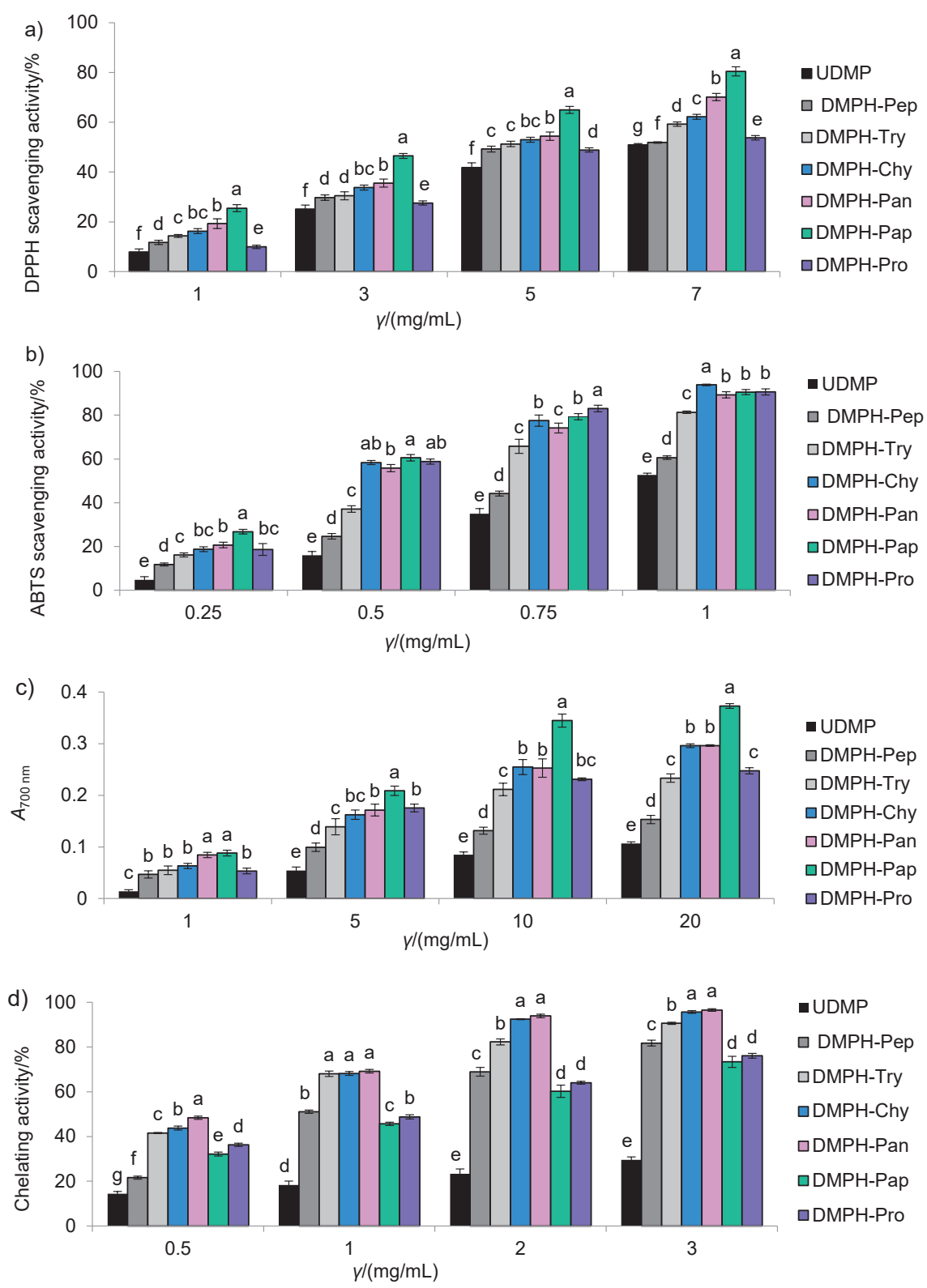

Fig. 4. Antioxidant activities of undigested dromedary milk proteins (UDMP) and their hydrolysates (DMPHs) as a function of their concentrations: a) DPPH radical-scavenging activity, b) ABTS radical-scavenging activity, c) FRAP (ferric reducing power assay), and d) iron(II) chelating activity. All results are expressed as mean value \pm S.D. of triplicate measurements; S.D.=standard deviation. Values with different lowercase letters at the same concentration are significantly different $(p<0.05)$ 
scavenging capacity was more pronounced in $\mathrm{DMPH}$ than in the UDMP $(p<0.05)$. These findings are similar to those by $\mathrm{Ku}$ mar et al. (15), indicating that dromedary casein hydrolysates had higher ABTS scavenging activity than intact dromedary caseins. DMPH-Pap had the lowest $\mathrm{IC}_{50}$ value $(0.417 \mathrm{mg} / \mathrm{mL})$, while UDMP had the highest $(0.967 \mathrm{mg} / \mathrm{mL})$. The $\mathrm{IC}_{50}$ values for the other hydrolysates were between 0.437 and $0.836 \mathrm{mg} /$ $\mathrm{mL}$. These results are in agreement with the hydrolysates from dromedary colostrum proteins (16). However, Oh et al. (40) reported higher IC $C_{50}$ values for cow's milk protein hydrolysates than those in the present study. These findings may be explained by the fact that dromedary milk possesses higher content of antioxidant proteins like $\alpha$-lactalbumin and $\beta$-casein than cow's milk $(9,14)$.

Both UDMP and DMPH scavenged more ABTS radicals than DPPH radicals. This difference could be due to the capacity of ABTS and DPPH radicals to diffuse in the reaction medium. ABTS is soluble in alcoholic and aqueous solutions and then it could easily react with peptides present in an aqueous medium. However, DPPH is soluble only in alcoholic solutions and may not reach readily the peptides in aqueous media. Subsequently, a high capacity to scavenge ABTS does not always implicate a high capacity to quench DPPH (41).

Fig. 4c presents the ferric reducing antioxidant power (FRAP) of UDMP and DMPH at various concentrations. The FRAP of all the samples was concentration dependent; it increased when the concentration of the samples increased. At all the tested concentrations, UDMP exhibited lower reducing power than DMPH $(p<0.05)$. The improvement of the FRAP of dromedary milk proteins after enzymatic hydrolysis might be due to the increased availability of peptides able to reduce iron(III) ions. At a concentration range from 5 to 20 $\mathrm{mg} / \mathrm{mL}$, DMPH-Pap, which exhibited the highest DPPH scavenging ability, had also the highest FRAP, while DMPH-Pep had the lowest FRAP. The difference in the FRAP among the hydrolysates might be assigned to the specificity of the used enzymes. Similar results were registered for dromedary and cow's milk casein hydrolysates $(15,33)$.

Fig. 4d illustrates the chelating activity of UDMP and $\mathrm{DMPH}$. The chelating power of $\mathrm{Fe}^{2+}$ increased considerably after the enzymatic hydrolysis of dromedary milk proteins. This observation could be due to the formation of amino acids with high metal-binding capacity (42). The hydrolysates chelated iron(II) ions in a concentration-dependent manner. The iron(II) chelating activity of the hydrolysates obtained from cow's milk proteins ( $1 \mathrm{mg} / \mathrm{mL}$ ) prepared by Conway et al. (43) did not exceed $25.5 \%$, while for DMPH (at the same mass concentration) it was in the range of 45.67-69.20\%. Indeed, dromedary milk contains higher amounts of lactoferrin than cow's milk, and this protein is known as a good iron chelator (11). Among the different hydrolysates, DMPH-Pan exhibited the lowest $I C_{50}$ value $(0.54 \mathrm{mg} / \mathrm{mL})$, followed by DMPH-Chy $(0.61 \mathrm{mg} / \mathrm{mL})$, while the highest one was obtained with DMPH-Pap $(1.35 \mathrm{mg} / \mathrm{mL})(p<0.05)$. The difference in the chelating capacity among hydrolysates could be due to the difference in their amino acid sequence and composition of peptides since they were generated using enzymes with different specificities.

\section{Effects of enzymatic hydrolysis on the functional properties of dromedary milk proteins}

Solubility of proteins is a significant attribute, which is required for use in many functional applications because it influences other properties like foaming and emulsifying capacities. Solubility of UDMP and DMPHs at different $\mathrm{pH}$ values is shown in Fig. 5a. Interestingly, enzymatic hydrolysis enhanced the solubility of dromedary milk proteins. Solubility of UDMP was minimum at $\mathrm{pH}=4.0$ (33.11\%), which is near the isoelectric point of dromedary milk caseins, and increased below and above this $\mathrm{pH}$ value. However, solubility of DMPHs exceeded $89 \%$ over the entire measured $\mathrm{pH}$ range. DMPH-Pro, with the highest $\mathrm{DH}(41.86 \%)$ and lowest molecular mass peptides, exhibited a high solubility (>98\%) at $\mathrm{pH}=4.0$ to 8.0 . The improvement of the solubility of protein hydrolysates could be explained by the reduction of the molecular mass of proteins and the increase of ionizable groups (amino and carboxyl groups), which could enable the protein to build hydrogen bonds with water (38).

The foaming properties of proteins depend on their capacity to migrate to the air-water interface in order to decrease the surface tension (44). Foaming capacity and foam stability of DMPH and UDMP are shown in Fig. 5b. The hydrolysates had higher foaming capacity than UDMP $(p<0.05)$. The highest foaming capacity was found in DMPH-Chy, DMPH-Pan and DMPH-Pap and it was $67.11,68.33$ and $69.44 \%$ respectively, whereas UDMP had the lowest foaming capacity $(7.22$ \%). Gani et al. (13) also indicated that enzymatic hydrolysis of cow's milk proteins increased foaming capacity. Its enhancement after enzymatic proteolysis could be due to the generation of amphiphilic peptides which could migrate more rapidly to the air-water interface to encapsulate air particles. Foaming expansion after whipping was monitored for 30 min to study the foam stability. DMPH-Try showed the highest foam stability $(23.06 \%)$. The foam stability decreased with time $(p<0.05)$, which is explained by the fact that some peptides did not have the capacity to maintain stable foam (13).

Emulsifying properties of DMPH and UDMP reported in terms of EAI and ESI are observable in Fig. 5c. The EAI indicates the capacity of a protein to form an emulsion, while ESI reflects the ability of an emulsion to maintain unvarying properties for a certain period (45). EAI were significantly higher $(p<0.05)$ in the hydrolysates than in the UDMP. The highest EAI was obtained with DMPH-Try $\left(28.18 \mathrm{~m}^{2} / \mathrm{g}\right)$. This could be due to the presence of high amounts of amphiphilic peptides in this fraction that possess a great flexibility at the oil/water interface, which results in a large surface area, and, enhance the formation of an emulsion. However, the lowest EAI value was found in DMPH-Pro, the hydrolysate with the highest $\mathrm{DH}\left(8.05 \mathrm{~m}^{2} / \mathrm{g}\right)$. This observation could be explained by the existence of small peptides, which are less efficient in 

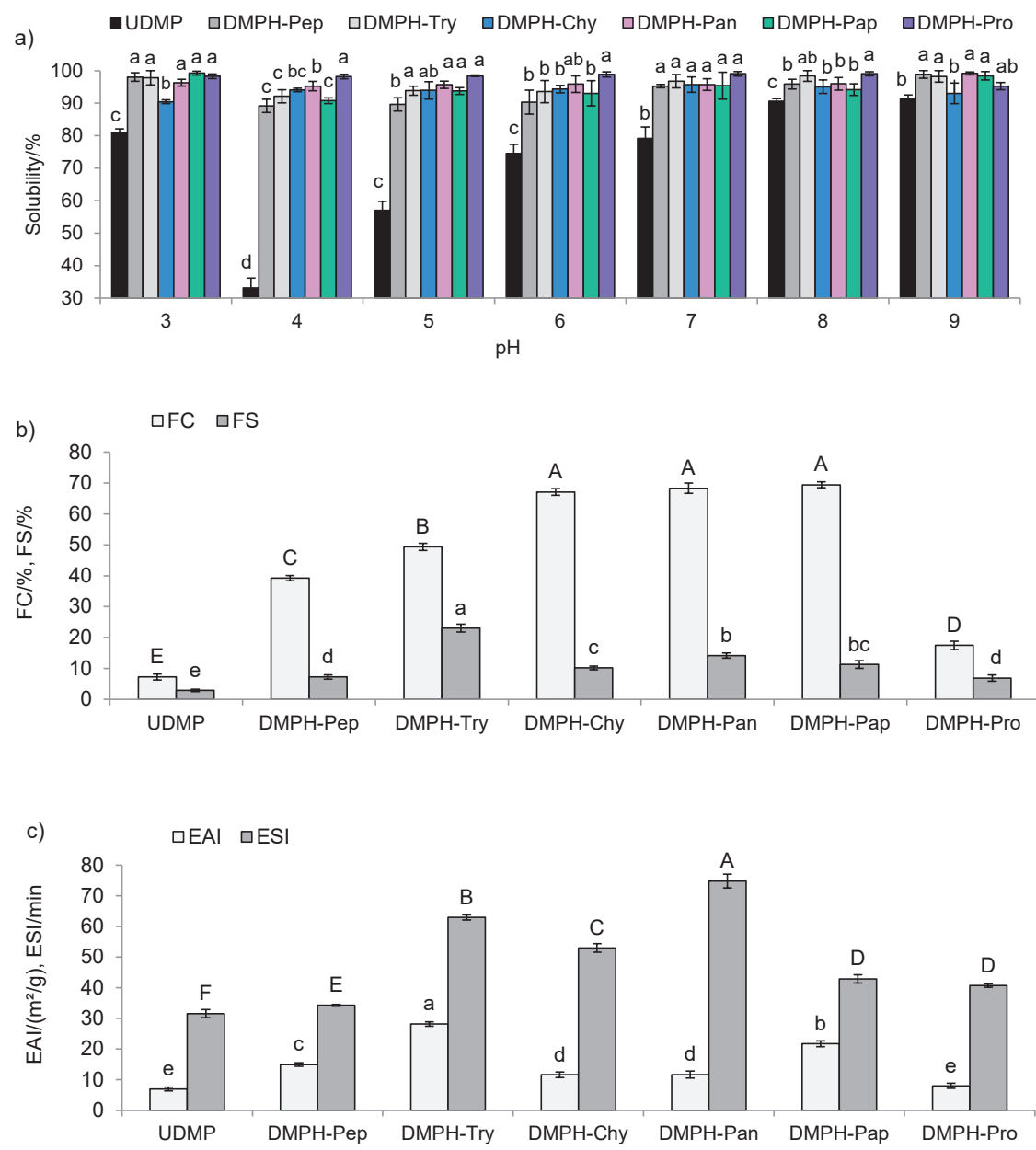

Fig. 5. Functional properties of undigested dromedary milk proteins (UDMP) and dromedary milk protein hydrolysates (DMPHs): a) solubility at the same $\mathrm{pH}$ : values with different lowercase letters are significantly different $(p<0.05), b)$ foaming properties: values with different lowercase letters indicate significant differences $(p<0.05)$ in foam stability $(F S)$ and values with different uppercase letters indicate significant differences in foaming capacity ( $F C)$, and $c$ ) emulsifying properties: values with different lowercase letters indicate significant differences $(p<0.05)$ in the emulsifying activity index (EAI) and values with different uppercase letters indicate significant differences in the emulsion stability index (ESI). All results are mean value \pm S.D. of triplicate measurements

emulsion stabilization (46). The ESI of the hydrolysates was in the range of 34.28-74.82 min and the highest value was found in DMPH-Pan $(p<0.05)$. Enzymatic hydrolysis generates peptides, which are surface active owing to their hydrophobic and hydrophilic groups. Thus, the EAI and ESI of the hydrolysates were enhanced. Emulsifying properties of the hydrolysates were influenced by the properties of the generated peptides including size, amphiphilicity and flexibility (46). In the same context, improvement of the emulsifying properties of cow's milk protein hydrolysates was found by Luo et al. (33).

\section{CONCLUSIONS}

In this work, different hydrolysates were prepared from dromedary milk proteins (DMPH) by single enzymes as well as a mixture of proteolytic enzymes. The degree of hydrolysis, SDS-PAGE, RP-HPLC and molecular mass distribution were studied to characterize the generated protein hydrolysates. DMPH exhibited significantly higher antioxidant activities, in various in vitro assays, than the undigested proteins. In addition, enzymatic hydrolysis of dromedary milk proteins enhanced the solubility, foaming and emulsifying properties. The differences in the antioxidant activities and functional properties among the hydrolysates could be due to the used enzymes since they have different specificities. Therefore, such DMPHs could be used as natural antioxidant ingredients in functional food formulations. Further investigations are needed to purify and identify potent antioxidant peptides from DMPHs and test them in vivo.

\section{ACKNOWLEDGEMENTS}

This work received support from the Arid Lands Institute of Medenine (Tunisia) and the Ministry of Higher Education and Scientific Research of Tunisia. 


\section{ORCID ID}

O. Ousaaief (ํ https://orcid.org/0000-0003-3785-6083

Z. Jrad (1) https://orcid.org/0000-0003-0463-4353

I. Adt ㄴ) https://orcid.org/0000-0002-4634-8120

T. Khorchani 으 https://orcid.org/0000-0003-2962-9526

\section{REFERENCES}

1. Mittler R. ROS are good. Trends Plant Sci. 2017;22(1):11-9. https://doi.org/10.1016/j.tplants.2016.08.002

2. Zuo L, Zhou T, Pannell BK, Ziegler AC, Best TM. Biological and physiological role of reactive oxygen species - The good, the bad and the ugly. Acta Physiol. 2015;214(3):329-48. https://doi.org/10.1111/apha.12515

3. Nwachukwu ID, Aluko RE. Structural and functional properties of food protein-derived antioxidant peptides. J Food Biochem. 2019;43(1):e12761. https://doi.org/10.1111/jfbc.12761

4. Barden L, Decker EA. Lipid oxidation in low-moisture food: A review. Crit Rev Food Sci Nutr. 2016;56(15):2467-82. https://doi.org/10.1080/10408398.2013.848833

5. Shahidi F, Ambigaipalan P. Phenolics and polyphenolics in foods, beverages and spices: Antioxidant activity and health effects - A review. J Funct Foods. 2015;18(Part B):820-97. https://doi.org/10.1016/j.jff.2015.06.018

6. Bamdad F, Shin SH, Suh JW, Nimalaratne C, Sunwoo H. Anti-inflammatory and antioxidant properties of casein hydrolysate produced using high hydrostatic pressure combined with proteolytic enzymes. Molecules. 2017;22(4):609-18.

https://doi.org/10.3390/molecules22040609

7. Abd El-Salam MH, El-Shibiny S. Preparation, properties, and uses of enzymatic milk protein hydrolysates. Crit Rev Food Sci Nutr. 2017;57(6):1119-32.

https://doi.org/10.1080/10408398.2014.899200

8. Kilara A, Panyam D. Peptides from milk proteins and their properties. Crit Rev Food Sci Nutr. 2003;43(6):607-33. https://doi.org/10.1080/10408690390251138

9. El-Hatmi H, Girardet JM, Gaillard JL, Yahyaoui MH, Attia $\mathrm{H}$. Characterisation of whey proteins of camel (Camelus dromedarius) milk and colostrum. Small Rumin Res. 2007;70(2-3):267-71.

https://doi.org/10.1016/j.smallrumres.2006.04.001

10. Bashir S, Al-Ayadhi LY. Effect of camel milk on thymus and activation-regulated chemokine in autistic children: Double-blind study. Pediatr Res. 2014;75(4):559-63. https://doi.org/10.1038/pr.2013.248

11. Mati A, Senoussi-Ghezali C, Zennia SSA, Almi-Sebbane D, El-Hatmi H, Girardet JM. Dromedary camel milk proteins, a source of peptides having biological activities - A review. Int Dairy J. 2017;73:25-37.

https://doi.org/10.1016/j.idairyj.2016.12.001

12. Brandelli A, Daroit DJ, Corrêa APF. Whey as a source of peptides with remarkable biological activities. Food Res Int. 2015;73:149-61.

https://doi.org/10.1016/j.foodres.2015.01.016

13. Gani A, Broadway AA, Masoodi FA, Wani AA, Maqsood S, Ashwar BA, et al. Enzymatic hydrolysis of whey and casein protein - Effect on functional, rheological, textural and sensory properties of breads. J Food Sci Technol. 2015;52(12):7697-709.

https://doi.org/10.1007/s13197-015-1840-1

14. Jrad Z, El Hatmi H, Adt I, Girardet JM, Cakir-Kiefer C, Jardin J, et al. Effect of digestive enzymes on antimicrobial, radical scavenging and angiotensin I-converting enzyme inhibitory activities of camel colostrum and milk proteins. Dairy Sci Technol. 2014;94(3):205-24. https://doi.org/10.1007/s13594-013-0154-1

15. Kumar D, Chatli MK, Singh R, Mehta N, Kumar P. Antioxidant and antimicrobial activity of camel milk casein hydrolysates and its fractions. Small Rumin Res. 2016;139:20-5.

https://doi.org/10.1016/j.smallrumres.2016.05.002

16. Oussaief O, Jrad Z, Adt I, Dbara M, Khorchani T, El-Hatmi H. Antioxidant activities of enzymatic-hydrolysed proteins of dromedary (Camelus dromedarius) colostrum. Int J Dairy Technol. 2020;73(2):333-40.

https://doi.org/10.1111/1471-0307.12668

17. Hoyle NT, Merritt JH. Quality of fish protein hydrolysates from herring (Clupea harengus). J Food Sci. 1994;59(1):76-9. https://doi.org/10.1111/j.1365-2621.1994.tb06901.x

18. Lowry $\mathrm{OH}$, Rosebrough NJ, Farr AL, Randall RJ. Protein measurement with the Folin phenol reagent. J Biol Chem. 1951;193(1):265-75.

19. Laemmli UK, Favre M. Maturation of the head of bacteriophage T4: I. DNA packaging events. J Mol Biol. 1973;80(4):575-99.

https://doi.org/10.1016/0022-2836(73)90198-8

20. Dupas C, Adt I, Cottaz A, Boutrou R, Molle D, Jardin J, et al. A chromatographic procedure for semi-quantitative evaluation of casein phosphopeptides in cheese. Dairy Sci Technol. 2009;89(6):519-29.

https://doi.org/10.1051/dst/2009027

21. Adt I, Dupas C, Boutrou R, Oulahal N, Noel C, Mollé D, et al. Identification of caseinophosphopeptides generated through in vitro gastro-intestinal digestion of Beaufort cheese. Int Dairy J. 2011;21(3):129-34.

https://doi.org/10.1016/j.idairyj.2010.10.002

22. Bersuder P, Hole M, Smith G. Antioxidants from a heated histidine-glucose model system. I: Investigation of the antioxidant role of histidine and isolation of antioxidants by 
high-performance liquid chromatography. J Am Oil Chem Soc. 1998;75(2):181-7. https://doi.org/10.1007/s11746-998-0030-y

23. Re R, Pellegrini N, Proteggente A, Pannala A, Yang M, Rice-Evans $C$. Antioxidant activity applying an improved ABTS radical cation decolorization assay. Free Radic Biol Med. 1999;26(9-10):1231-7.

https://doi.org/10.1016/S0891-5849(98)00315-3

24. Wu HC, Chen HM, Shiau CY. Free amino acids and peptides as related to antioxidant properties in protein hydrolysates of mackerel (Scomber austriasicus). Food Res Int. 2003;36(910):949-57.

https://doi.org/10.1016/S0963-9969(03)00104-2

25. Zhu K, Zhou H, Qian H. Antioxidant and free radical-scavenging activities of wheat germ protein hydrolysates (WGPH) prepared with alcalase. Process Biochem. 2006;41(6):1296-302.

https://doi.org/10.1016/j.procbio.2005.12.029

26. Tsumura K, Saito T, Tsuge K, Ashida H, Kugimiya W, Inouye K. Functional properties of soy protein hydrolysates obtained by selective proteolysis. LWT - Food Sci Technol. 2005;38(3):255-61.

https://doi.org/10.1016/j.lwt.2004.06.007

27. Shahidi F, Han XQ, Synowiecki J. Production and characteristics of protein hydrolysates from capelin (Mallotus villosus). Food Chem. 1995;53(3):285-93.

https://doi.org/10.1016/0308-8146(95)93934-J

28. Pearce KN, Kinsella JE. Emulsifying properties of proteins: Evaluation of a turbidimetric technique. J Agric Food Chem. 1978;26(3):716-23.

https://doi.org/10.1021/jf60217a041

29. SPSS v. 22.0 software, professional edition, SPSS Inc., Chicago, IL, USA; 2013.

30. Cheng X, Tang X, Wang Q, Mao XY. Antibacterial effect and hydrophobicity of yak K-casein hydrolysate and its fractions. Int Dairy J. 2013;31(2):111-6. https://doi.org/10.1016/j.idairyj.2012.12.004

31. Espejo-Carpio FJ, García-Moreno PJ, Pérez-Gálvez R, Morales-Medina R, Guadix A, Guadix EM. Effect of digestive enzymes on the bioactive properties of goat milk protein hydrolysates. Int Dairy J. 2016;54:21-8.

https://doi.org/10.1016/j.idairyj.2015.10.006

32. Banach JC, Lin Z, Lamsal BP. Enzymatic modification of milk protein concentrate and characterization of resulting functional properties. LWT - Food Sci Technol. 2013;54(2):397-403.

https://doi.org/10.1016/j.lwt.2013.06.023

33. Luo Y, Pan K, Zhong Q. Physical, chemical and biochemical properties of casein hydrolyzed by three proteases: Partial characterizations. Food Chem. 2014;155:146-54.

https://doi.org/10.1016/j.foodchem.2014.01.048
34. Frackenpohl J, Arvidsson PI, Schreiber JV, Seebach D. The outstanding biological stability of $\beta$-and $\gamma$-peptides toward proteolytic enzymes: An in vitro investigation with fifteen peptidases. ChemBioChem. 2001;2(6):445-55.

https://doi.org/10.1002/1439-

7633(20010601)2:6<445::AID-CBIC445>3.0.CO;2-R

35. González-Rodríguez MC, Gonzalo C, San Primitivo F, Cármenes P. Relationship between somatic cell count and intramammary infection of the half udder in dairy ewes. J Dairy Sci. 1995;78(12):2753-9.

https://doi.org/10.3168/jds.S0022-0302(95)76906-5

36. Nongonierma AB, FitzGerald RJ. The scientific evidence for the role of milk protein-derived bioactive peptides in humans: A review. J Funct Foods. 2015;17:640-56.

https://doi.org/10.1016/j.jff.2015.06.021

37. Amiot J, Germain L, Turgeon S, Lemay M, Ory-Salam C, Auger FA. Peptides from milk protein hydrolysates to improve the growth of human keratinocytes in culture. Int Dairy J. 2004;14(7):619-26.

https://doi.org/10.1016/j.idairyj.2003.11.007

38. Lacou L, Léonil J, Gagnaire V. Functional properties of peptides: From single peptide solutions to a mixture of peptides in food products. Food Hydrocoll. 2016;57:187-99. https://doi.org/10.1016/j.foodhyd.2016.01.028

39. Saadi S, Saari N, Anwar F, Hamid AA, Ghazali HM. Recent advances in food biopeptides: Production, biological functionalities and therapeutic applications. Biotechnol Adv. 2015;33(1):80-116.

https://doi.org/10.1016/j.biotechadv.2014.12.003

40. Oh NS, Lee HA, Lee JY, Joung JY, Lee KB, Kim Y, et al. The dual effects of Maillard reaction and enzymatic hydrolysis on the antioxidant activity of milk proteins. J Dairy Sci. 2013;96(8):4899-911.

https://doi.org/10.3168/jds.2013-6613

41. Corrêa APF, Daroit DJ, Coelho J, Meira SMM, Lopes FC, Segalin J, et al. Antioxidant, antihypertensive and antimicrobial properties of ovine milk caseinate hydrolyzed with a microbial protease. J Sci Food Agric. 2011;91(12):2247-54. https://doi.org/10.1002/jsfa.4446

42. Teixeira B, Pires C, Nunes ML, Batista I. Effect of in vitro gastrointestinal digestion on the antioxidant activity of protein hydrolysates prepared from Cape hake by-products. Int J Food Sci Technol. 2016;51(12):2528-36.

https://doi.org/10.1111/ijfs.13233

43. Conway V, Gauthier SF, Pouliot Y. Antioxidant activities of buttermilk proteins, whey proteins, and their enzymatic hydrolysates. J Agric Food Chem. 2013;61(2):364-72. https://doi.org/10.1021/jf304309g

44. Çabuk B, Stone AK, Korber DR, Tanaka T, Nickerson MT. Effect of Lactobacillus plantarum fermentation on the surface and functional properties of pea protein-enriched flour. Food Technol Biotechnol. 2018;56(3):411-20. https://doi.org/10.17113/ftb.56.03.18.5449 
45. Thaiphanit S, Anprung P. Physicochemical and emulsion properties of edible protein concentrate from coconut $(\mathrm{CO}$ cos nucifera L.) processing by-products and the influence of heat treatment. Food Hydrocoll. 2016;52:756-65.

https://doi.org/10.1016/j.foodhyd.2015.08.017
46. Klompong V, Benjakul S, Kantachote D, Hayes KD, Shahidi F. Comparative study on antioxidative activity of yellow stripe trevally protein hydrolysate produced from Alcalase and Flavourzyme. Int J Food Sci Technol. 2008;43(6):1019-26.

https://doi.org/10.1111/j.1365-2621.2007.01555.x 